Acta Universitatis Wratislaviensis • No 3869

Literatura i Kultura Popularna XXIV, Wrocław 2018

DOI: $10.19195 / 0867-7441.24 .3$

\title{
Andrea Virginás
}

ORCID: 0000-0003-1867-1083

Sapientia Hungarian University of Transylvania, Romania

\section{Film genre patterns and complex narrative strategies in the service of authorship*}

Keywords: film genre, complex narration, author cinema, generic allegory, contemporary film

Słowa kluczowe: gatunki filmowe, złożoność narracyjna, kino autorskie, alegoria gatunkowa, kino współczesne

\section{Introduction}

As the title of the article indicates, I am working with three categories of analysis: film genre(s), film(ic) narratives and filmmakers on their way to acquiring authorial status. These entities - genre, narration, authorship - obviously influence each other in any medium, not only film, and what I aim to present is a possible story of how this process of mutual interdependence might be unfolding in contemporary Euro-American film. The observation of Edward Buscombe in his seminal text "The idea of genre in the American cinema" provides a set focus with its reference to the intertwining of individual goals and inhabiting generic patterns on the part of the filmmakers (directors): "[ $\mathrm{t}]$ he artist brings to the genre his or her own concerns, techniques, and capacities — in the widest sense, a style — but receives from the genre a formal pattern that directs and disciplines the work". 1

The present paper is extracted from a longer analysis ${ }^{2}$ that covers four film directors — Vincenzo Natali, Darren Aronofsky, Tom Tykwer and Christopher

* This work was supported by a grant of the Romanian Ministry of Research and Innovation (CNCS - UEFISCDI), Exploratory Research Project no. PN-III-P4-ID-PCE-2016-0418, PNCDI III.

${ }^{1}$ E. Buscombe, "The idea of genre in the American cinema", [in:] Film Genre Reader IV, ed. B.K. Grant, Austin 2012, p. 22.

2 This has been published in Hungarian. See: A. Virginás, "Elsőfilmek és müfaji allegóriák. Komplex narratív eljárások Natali, Aronofsky, Tykwer és Nolan filmjeiben”, Metropolis 1, 2012, pp. 56-71, http://www.metropolis.org.hu/?pid=16\&aid=451 (accessed: 21.12. 2017).

Literatura i Kultura Popularna 24, 2018

(C) for this edition by CNS 
Nolan — and eight of their films. Their smaller-budget debut features presented in 1997-1998 (Cube by Canadian Vincenzo Natali [1997], P $i$ by American Darren Aronofsky [1998], Run, Lola, Run by German Tom Tykwer [1998], and Following by English-American Christopher Nolan [1998]) are compared to the following equally big-budget, Hollywood-controlled, global hits produced after a decade: Splice (dir. Natali, 2009), Black Swan (dir. Aronofsky, 2010), The International (dir. Tykwer, 2009), and Inception (dir. Nolan, 2010). What happened between the earlier and later films from these pairs, e.g. Cube and Splice, or Pi and Black Swan? This paper is a trace of the efforts to understand and to conceptualize the decade separating these debut films and global hits of the same directors, all members of the X-generation caught between the analogue past and the digital present, as well an attempt to theorize upon the similar authorial trajectories and poetic solutions seen in four different cases of contemporary Euro-American cinema.

\section{Narration in two sets of examples}

Questions of narration are but one segment of my analysis, however, a truly essential segment. Without the ongoing discussion referring to complex narratives in contemporary film (exemplified by the names of David Bordwell, Thomas Elsaesser, Warren Buckland, and Eleftheria Thanouli ${ }^{3}$ ), I would not have had the occasion to create my corpus of analysis and compare its elements in terms of their narrative designs. The aforementioned corpus is examined from the perspective of how narratively complex structures are created in low-budget, arthouse and regional first features made in the late 1990s, and in big-budget, Hollywood-funded and/or distributed hits made a decade later. While the overall theoretical background is presented in relation to the four directors, I have to limit myself here to two directors and their films in order to introduce my analysis.

In describing the narratively complex structures in the corpus under analysis, what I found extremely helpful was Jan Simons's conception presented in Playing the Waves: Lars von Trier's Game Cinema. ${ }^{4}$ Simons's conception relies on the similarities between narratives — as based on Roland Barthes's "cardinal functions" 5 and the "semiotic square" — and games understood as strategies. Si-

${ }^{3}$ D. Bordwell, "Film futures", [in:] Poetics of Cinema, New York 2007, pp. 171-187; W. Buckland, "Introduction: Puzzle plots", [in:] Puzzle Films: Complex Storytelling in Contemporary Cinema, ed. W. Buckland, Malden 2009, pp. 1-13; T. Elsaesser, "The mind-game film", [in:] Puzzle Films: Complex Storytelling in Contemporary Cinema, ed. W. Buckland, Malden 2009, pp. 13-41; E. Thanouli, Post-Classical Cinema: An International Poetics of Film Narration, London 2009.

4 J. Simons, Playing the Waves: Lars von Trier's Game Cinema, Amsterdam 2007.

5 "Roland Barthes identified the 'cardinal functions' of a story as the units that refer to actions which 'open (or continue, or close) an alternative that is of direct consequence for the subsequent development of the story, in short that [...] inaugurate or conclude an uncertainty'. Cardinal functions propel the story forwards and engage the reader or spectator by raising questions, delaying 
mons argues that "[ $\mathrm{t}]$ he difference between the semiotic square and the strategic form of a game does not reflect an essential difference between narratives and games, but is more of a matter of perspective. Narratives are, after all, organised around the choices of their protagonists". 6 Because of the cardinal functions (and the corresponding nodes) determining the characters' possible choices, and even though in a narrative (irrespective of its medium) these "are not made by the spectator or reader of a story", Simons concludes that "the logic of 'hermeneutic' and 'proairetic' codes in narratives is very similar to the logic of games". 7 In the spirit of Simons's vision of narratives as games, I identify reductionist strategies along with the creation of narratively complex structures in the mentioned films, and, similarly to others working with complex film narratives, I argue that through a reduction of the parameters of space (Natali) and time (Tykwer), or the number of focalizer subjectivities (Aronofsky), and by deconstructing linear causal chains (Nolan), directors create narrative situations which resemble games, especially in the case of low-budget debut features produced in regional arthouse and/or television contexts.

In Natali's first feature, Cube, seven characters find themselves in a giant closed structure made up of cubes, and the film presents their efforts to understand their situation, as well as to find a way out of this highly symbolic prison. We are presented with a slow, present-tense narration, coupled with a claustrophobic space structure, which entails that we, as viewers, are to face a similar fate to the prisoners caught in the cube-like labyrinth. The characters cannot generate cause-and-effect, linear explanations, and neither can we, thus are unable to project possibilities into the future. Visually, this is conveyed through the fact that our view is blocked by walls in the basic colours, decorated with abstract patterns, while the widest framing varies between American plans and medium totals. Meanwhile, close-ups are hardly used because of their effect of generating empathy and emotions.

A type of space that is fully interior, enclosing on the characters, and also abstract to a high degree, defines and also represents the narrative junctions therefore. This resonates deeply (with)in the fate of the disoriented characters, average kind of people, none of them possessing extra information or knowledge that would allow for an elevated omniscient view. The narrative structure of Cube may be modelled as a series of decisions leading to life or death, decisions taken while their causes and effects are hardly known: once in the giant structure, the charac-

resolutions, suggesting alternative possibilities, triggering hypotheses and generating curiosity and suspense, all of which depend on the possibility of at least two alternative continuations". J. Simons, op. cit., p. 186. Simons refers to: R. Barthes, Image, Music, Text: Essays Selected and Translated by Stephen Heath, London 1977, pp. 93-94.

6 J. Simons, op. cit., p. 186.

7 Ibid. In this quotation Simons refers to: [1] R. Barthes, S/Z, Paris 1970, p. 26; and [2] P. O’Neill, Fictions of Discourse: Reading Narrative Theory, Toronto 1996, p. 41. 
ters start moving throughout the cubes, but some of them are deadly traps, with horrific objects butchering human bodies. Thus, it comes as no surprise that the cause-and-effect linearities are all destroyed at some point. We may think in this respect about the meta-narratives that the protagonists come up with to rationalize their sudden existence in the cube, meta-narratives that turn out to be dead-ends after all. Holloways' paranoid conspiracy theory; Rennes' empirical boots-test (to which he himself falls prey to); Leuven's exceptional mathematical knowledge of prime numbers, the limits of which appear when a long series of numbers must be handled as clues to the deadliness of the next cube; or the meta-narrative of the genius shadowed by mental shortcomings in the case of Kazan; and finally Quentin's popular psychological approach, which relies on interior motives of human beings - instead of on mysteries related to space-structures and numbers. This latter strategy seems to take the survivor closest to the success of escaping otherwise.

In Splice, Natali's big-budget success feature made ten years later, cubes and interior space structures similar to giant boxes are essential again. The protagonists, biochemists Elsa and Clive, spend most of their time in laboratories, working with genetically modified organisms stored in boxes and living in incubators. By breaking the law and disobeying the orders of their superiors they create a human-animal hybrid splice. The creature bursts out of the artificial womb much earlier than expected, hardly escaping alive the heavy metal structure: in this respect Dren, the spliced human-animal organism, resembles the enclosed group from Cube. A similar structure of strategies being started, tested, denied or upheld may be seen to govern the game structures of both Cube and Splice. However, while in the world of Cube cause-and-effect chains - beginning from point zero or represented in progress - appear in front of our eyes as if naked and with immediate consequences for the characters' life or death, Splice may be situated in another type of discourse.

Not independent of the film's digitally produced, richly textured and saturated audiovisual material, the imaginary cause-and-effect chains are being initiated and/or denigrated in a higher number, while also being much more figural, dense and of a decorative nature than was the case in the director's first feature. One such cause-and-effect chain in Cube - that has a beginning, a middle and an end - corresponds to the characters' (life) trajectories, and this also happens in the very literal sense of (their) crawling through the interconnected cubic rooms. In the discourse of Splice this abstract model might be retrieved from the high variety of genetically modified beings, communicated to us under a variety of forms: chemical and biological codes represented on the computer screens of the scientists; living creatures of flesh and blood; shapeless material ending their life before our very eyes; and also objects of an almost museum-like exhibition after their death. The corpses of these causal chains are exposed in the laboratory, under names with such popcultural allusions as Syd and Nancy, or Bacall and Bo- 
gart, but also Fred and Ginger, the very first genetically modified beings we meet at the start of the film, well before the main sensation, Dren comes to the forefront. Dren, the already mentioned human-animal hybrid organism is literally the result of a series of accidents: Elsa and Clive are having their research funds withdrawn unexpectedly, in spite of their evident progress, therefore they revolt by continuing their experiments secretly; Elsa sneaks her own DNA material into the pot; the procedure of cloning and splicing turns out to be successful; the being created survives several situations when her life is threatened. Dren is an accident, truly.

In the diegetic world of the movie, Dren literally embodies causal chains that have a beginning, a middle and an end, and she does so from a biological-evolutionary perspective too, with her/his sequentially changing characteristics: from humanoid fetus on to amphibian, then on to bird, then developing into a woman who changes into a man, and finally flies away as a mythological being at the end of the film. Dren also mirrors the cause-and-effect chains and multiple possibilities that may be construed from the protagonists' deeds and activities, and due to this feature she may be attributed meta-narrative power. Containing Elsa's DNA in the process of splicing, hybridizing and cloning, Dren is Elsa, the womanscientist moving the narrative forward; however, she is Elsa's daughter as well, and one of the most interesting strands of the film is the story of how emotionally traumatized, extremely intelligent Elsa re-configures herself as a nurturing mother-being. Furthermore, Dren also contains the possibility of being Elsa's lover, and, after having changed her sex, metamorphoses into the father of her sexually reproduced, and therefore classical biological child, as Elsa appears heavily pregnant in the final moments of the film. But the possibilities of the plot - and of Dren's character - do not stop here: she is the adopted daughter of Elsa's partner, Clive, and also his lover, thus Elsa's enemy/opponent in the most melodramatic plot twist.

Choices that lead to life-or-death dead ends, and the impossibility to fully recognize them because of being embedded in the diegetic situation, are being formulated as such in another climactic scene of Splice, where the puritan mode of representation, well known from Cube, is restaged. Elsa and Clive meet in their formerly (over)valued home, after Elsa had witnessed the hybrid Dren and her partner Clive making love in the barn close to the woods. "We changed the rules, and we can't tell wrong from good any more," exclaims the embarrassed, but also truly horrified Clive. This moment of realizing that the rules might change, and that they are actually changed at some point, yields some truly positive results in Cube, which maps narrative complexity by trial and error and by offering the audience an intensely self-conscious, also cognitively demanding viewing position. Through realizing that rules change within the giant structure, the survivors in Cube are capable of integrating the (third) dimension of time, and consequently that of movement within the system of cubes, thus, they may envisage and find the bridge that will lead them out of the monstrous place/space. In Splice, through this 
moment of rule-changing awareness, we seemingly return to the field of interpretation constituted by human relationships and sexuality understood as psychology. This will entail the true tragedy as defined by this context of meaning, that is, the sequentially changing hybrid creature raping and/or murdering her biological and adoptive parents.

The films of Vincenzo Natali display a heightened sensibility towards the moments, nature and mechanisms of taking decisions that result in cause-and-effect, or causal chains, thus we could imagine these films as attentive research procedures aimed at those narrative building bricks that Roland Barthes named cardinal functions. As for Darren Aronofsky, it is not so much a narrative tree to be drawn from the choices and decisions made by the protagonists that emerges as a route to narratively complex filmic worlds. The American director is keen on creating and representing story-possibilities enabled by his chosen generic narrative paradigm (the psycho-thriller), that are mutually (or even multiply) exclusive, and then conveying these ambiguities through narrative and representational methods that are highly subjective and also over-aestheticized. His first feature, $P i$, and his widely-known Black Swan are both portraits of highly specific psychological syndromes, channelled through the perception and information-processing mechanisms of the protagonists. The anti-social genius mathematician with blackouts in $P i$ and the perfectionist ballet-dancer consumed by her frustrations in Black Swan have unconventional psychological designs. These features are conveyed through the perception-modes (basically moving-visual and moving-auditive, as made possible by the filmic medium), observations, moods and experiences of the characters.

We may describe Aronofsky as a filmmaker interested in creating and upholding such narratives where decisions and choices do not have to be made in the narration because the focalizer protagonists themselves cannot make such choices due to their blurred mental and perceptional capacities. The trajectory of Aronofsky starts from the first film in 1997, $P i$, where no outer control is exerted over the mutually and multiply exclusive possibilities and the viewer remains with an experience of undecidability after repeated viewings of the films. The 2010 Black Swan narrows the upheld possibilities to two - a characteristic of the film's narrative strategy which should be related to the movie's Hollywood big-budget background - that is, the version of the tormented ballerina versus that of the surrounding world as embodied by her mother, her male choreographer and her female rival-friend. In both his first film and his big hit, Aronofsky works with highly subjective filmic narration, where the narratively complex structures emerge through the simultaneous creation and statement of opposing, mutually excluding events in the plot and also in the story, which thus cannot be checked and validated as true or false within the generic world created. This scheme is very effectively hidden by the key characteristic of Aronofsky's poetics: the usage of such highly particular and thus truly intensive markers of afilmic and profilmic 
reality as such the New York metro at night, bodies sweating and aching while performing stressful physical and/or mental work, etc.

According to the first part of my main argument, Natali and Aronofsky (also Tykwer and Nolan) in their first features construct complex narrative structures, while also remaining within the confines of the sincere and unambiguous hybrid genres that in the long run will define their work as auteurs: the horror sci-fi for Natali and the psycho-thriller for Aronofsky. ${ }^{8}$ Based on this, I propose a conclusion referring to these authors' attitudes towards genre usage, attitudes that seem to change over the period separating the analyzed directors' debut features from their big-budget Hollywood successes.

\section{(Narrative) complexity and genre usage}

Questions of narrative complexity may be subordinated to the wider discourse on complex structures and phenomena of complexity, used to make sense of a globalized, electronically and materially interconnected post-human environment. In a 2011 review article on the topic, Ien Ang emphasizes that in such a context, besides descriptions of complexity, priority must be given to solutions that offer themselves as paths of navigation through globally complex phenomena. As for a short definition of what complexity in the world and in narratives might mean, Ang cites Mol and Law: "There is complexity if things relate but don't add up, if events occur but not within the processes of linear time, and if phenomena share a space but cannot be mapped in terms of a single set of three-dimensional coordinates". 9 In other words, what characterizes the complexity turn is an emphasis on irreducible multiplicity, historical undecidability, and the simultaneous presence of contradictory elements, under the logic of both/and (rather than either/or)". ${ }^{10}$ Warren Buckland, in the introductory chapter to Puzzle Films, translates these characteristics to filmic narration in the following manner: "[How do puzzle plots go beyond Aristotle's definition of the complex plot? The chapters in this volume demonstrate that] puzzle films embrace nonlinearity, time loops, and fragmented spatio-temporal reality. These films blur the boundaries between different levels of reality, are riddled with gaps, deception, labyrinthine structures, ambiguity, and overt coincidences. They are populated with characters who are schizophrenic, lose their memory, are unreliable narrators, or are dead (but without us - or them — realizing). In the end, the complexity of puzzle films operates

\footnotetext{
${ }^{8}$ A statement I make in the long version of the paper for Tykwer and the action film and the noir detection film and Nolan.

9 Ang cites A. Mol, J. Law, “Complexities: An introduction”, [in:] Complexities: Social Studies of Knowledge Practices, eds. J. Law, A. Mol, Durham 2002, p. 1.

${ }^{10}$ I. Ang, "Navigating complexity: From cultural critique to cultural intelligence", Continuum: Journal of Media \& Cultural Studies 25, 2011, no. 6, pp. 783-784.
} 
on two levels: narrative and narration. It emphasizes the complex telling (plot, narration) of a simple or complex story (narrative)". ${ }^{11}$

The directors examined here have achieved worldwide success with their first feature films, while also creating complex narrative structures further refined in their following films, as was the case with Nolan's Following and Memento (2002), or Tykwer's Run, Lola, Run and Perfume (2006). Their films (among others, of course) became the very material that allowed for working out the category of "puzzle films" in the volume edited by Warren Buckland (in the texts of Buckland, Elsaesser, Ghislotti, Wedel, Cameron and Cubitt ${ }^{12}$ ), seen as different from Aristotelian complex storytelling, but also from Bordwell's forking-path narratives. ${ }^{13}$ This is a rather beneficial development from my point of view. I can rely on these findings while arguing that the differences between the first films and the big hits of these directors - though certainly attributable to different production and distribution contexts - might (also) be explained based on the changing roles that complex narrative designs and generic patterns are assigned.

As I see it, Natali, Aronofsky, Tykwer and Nolan set out to reform classical storytelling through complex narrative choices in their first, debut features, and this may be considered a strong cause for their acquiring authorial profiles, in spite of their ardent interest in one filmic genre which they pursue (as mentioned earlier: horror science-fiction, psycho-thriller, action film, noir detection film). I also think that — on the route leading from low-budget first films to big-budget mainstream hits - we witness complex narrative structures being transformed to resemble more classical narrative storytelling. This development may be attributed to film industrial and film production causes, but also to the compelling structures that film genres - even if hybridized - entail. However, I also argue that close comparative analysis of the mentioned eight films, enabled by the concepts and methods of classical versus complex filmic storytelling, demonstrates that the "simplification" and/or repetition of (complex) narrative designs that have characterized the first films is accompanied by a different usage of generic patterns in the Hollywood-originating hits.

11 W. Buckland, "Introduction", [in:] Puzzle Films: Complex Storytelling in Contemporary Cinema, ed. W. Buckland, Malden 2009, p. 6.

12 W. Buckland, "Making sense of Lost Highway", [in:] Puzzle Films: Complex Storytelling in Contemporary Cinema, ed. W. Buckland, Malden 2009, pp. 42-61; T. Elsaesser, op. cit., pp. 13-41; S. Ghislotti, "Narrative comprehension made difficult: Film form and mnemonic devices in Memento", [in:] Puzzle Films: Complex Storytelling in Contemporary Cinema, ed. W. Buckland, Malden 2009, pp. 87-106; M. Wedel, "Backbeat and overlap: Time, place and character subjectivity in Run, Lola, Run", [in:] Puzzle Films: Complex Storytelling in Contemporary Cinema, ed. W. Buckland, Malden 2009, pp. 129-150; A. Cameron, S. Cubbitt, "Infernal Affairs and the ethics of complex narrative", [in:] Puzzle Films: Complex Storytelling in Contemporary Cinema, ed. W. Buckland, Malden 2009, pp. 151-166.

13 D. Bordwell, op. cit., pp. 171-187. 
In the 2009 edition of The Routledge Companion to Film and Philosophy, Brian Laetz and Dominic McIver Lopes elaborate on the concept of genre, starting from a pragmatic description of the way genre as such (it) is employed: "Two tasks are obvious: genres help with interpretation and with appreciation. Movie audiences deploy genre concepts as they interpret and appreciate, and filmmakers also work with an eye to genre as long as they aim to make movies to be interpreted and appreciated". ${ }^{14}$ Through this process of both creators and audiences considering genre now and then, we may differentiate between the two, historically dominant modes of referencing generic patterns. The first is a schematic recreation of these patterns, done with sincere intent and often considered boring, as Barry Keith Grant and Malisa Kurtz aptly observe: "[...] every new genre film always already exists in relation to and gains part of its meaning from the generic texts that preceded it. Every genre film is haunted by earlier work in the genre [...]". ${ }^{15}$ The second dominant mode, the (sometimes ironic) re-interpretation, and also, consequently, hybridization of various generic patterns is also postulated/in Rick Altman's axiomatic observation: "We need to recognize that not all genre films relate to their genre in the same way or to the same extent". ${ }^{16}$ However, based on Laetz and McIver Lopes's "ontological" definition of film genre we may easily describe a third mode of genre-usage, which has been greatly facilitated by digital platforms in filmmaking, even though it is not exclusively linked to it.

Laetz and McIver Lopes give the following ontological definition of genre: "An improved realist proposal is that movie genres are types. Each type has a type-constitutive feature, a feature that items must have in order to be tokens of the type. [...] Perhaps, then, movie genres are types whose tokens are movies having whatever features constitutes the type. [...] The advantage of this proposal is that the identity of a genre is secured not by its tokens but by a feature that they have. Movies actually made in a movie genre are not essential to it. Thus the comparison class in appreciating a movie in a genre may go beyond movies actually made in the genre". ${ }^{17}$ Supported by the idea that movie genres are types not fully determined by the actual movies belonging/categorized in that genre ${ }^{18}$ allows for

14 B. Laetz, D. McIver Lopes, "Genre", [in:] The Routledge Companion to Philosophy and Film, eds. C.R. Plantinga, P. Livingstone, London-New York 2009, pp. 152-161.

15 B.K. Grant, M. Kurtz, "Introduction", [in:] Notions of Genre: Writings on Popular Film before Genre Theory, eds. B.K. Grant, M. Kurtz, Austin 2016, p. 1.

16 R. Altman, "A semantic/syntactic approach to film genre", [in:] Film Genre Reader IV, ed. B.K. Grant, Austin 2012, p. 34.

17 B. Laetz, D. McIver Lopes, op.cit., p. 158.

${ }^{18}$ Leger Grindon formulates a similar idea starting from the Wittgensteinian/Lakoffian concept of prototype: "The prototype concept, associated with George Lakoff, argues that categories have gradations of membership. Prototypical works that display a vivid set of properties central to the category act as exemplary models at the hub of the system, giving the genre stability. Other participants receding from these model examples exhibit weaker qualifications and, those at the boundaries are only marginally identifiable with the group. So benchmark hits in a genre [...] serve as prototypes, but even marginal works $[\ldots]$ can still be understood to participate by employing 
postulating the third type of film genre usage: when generic patterns are used in order to evoke and represent the cultural codes and symbolic meanings attached to them, and it is this mode that I call allegorical genre usage.

Before proceeding with my analysis, I do want to make clear the sense I attribute to allegory and allegorical structures. Hungarian literary theorist Antal Bókay gives the following definition and description of allegory, based on Northrop Frye and Paul de Man: "It is the disjunctive feature of allegory that is usually emphasized (that is building into one semantic system two quite different phenomena, while also keeping them apart). According to Northrop Frye, one can speak of allegory if "parts of a narrative evidently and continuously refer to another simultaneous event - or thought — structure, which may be historical events, moral or philosophical thoughts, but natural events as well' [1]. Paul de Man observes that allegory is sequential and narrative, but the theme of its narration is not compulsorily temporal [...] [2]". ${ }^{19}$ Generic patterns are both sequential and narrative, and their first-order meanings are also well-known and evident, however, the meanings of the genre understood as a type in Laetz and McIver Lopes's sense may be different - thus, one can suggest that the most recent big-budget features of the directors under analysis are intent on allegorically representing cultural and symbolical codes attached to the basic genres. Splice is full of sci-fi and horror stereotypes and icons, and pushes these to baroque extremes, where they become the object of immersive pleasures. Thus, it can be defined at once a sincere genre film, and a movie-length allegorical structure, a representation that makes a statement (about) of the chosen (hybrid) genre defined in the sense of Laetz and McIver Lopes as a type that does not need to rely on the concrete films for its existence.

Vivian Sobchack gives the following "essential" definition in conclusion to her comparative analysis of horror and sci-fi: "Both genres deal with chaos, with the disruption of order, but the horror film deals with moral chaos, the disruption of natural order (assumed to be God's order), and the threat to the harmony of hearth and home; the SF film, on the other hand, is concerned with social chaos, the disruption of social order (man-made), and the threat to the harmony of civilized

some of the genre's conventions. Films may range over multiple genres by mixing together different generic qualities. Celestino Deleyto contends that genres are constituted by the conventions in which films participate, but conversely those conventions are identified by the prototypical works that employ them" - L. Grindon, "Cycles and clusters: The shape of film genre history", [in:] Film Genre Reader IV, ed. B.K. Grant, Austin 2012, p. 43. Jörg Schweinitz presents a similar opinion in his highly interesting Film and Stereotype: A Challenge for Cinema and Theory, transl. L. Schleussner, New York 2011.

19 A. Bókay, Irodalomtudomány a modern és a posztmodern korban, Budapest 1997, p. 414. Bókay refers to: [1] N. Frye, Spiritus Mundi: Essays on Literature, Myth and Society, Bloomington 1976, p. 12; and [2] P. de Man, "Pascal's allegory of persuasion", [in:] Allegory and Representation, ed. S. Greenblatt, Baltimore 1981, p. 1. 
society going about its business". ${ }^{20}$ Natali's first film, Splice, may be considered a slow, detailed analysis of this definition, and Sobchack's framework also allows us to see how the Canadian director is positioned on the borderland between the two genres. Cube illustrates moral chaos and the falling apart of civilized bureaucratic society, while Splice considers threats referring to home, hearth and social order. Both films offer what Susan Sontag calls "the technological view" of science-fiction films: "Science fiction films invite a dispassionate, aesthetic view of destruction and violence - a technological view. Things, objects, machinery play a major role in these films". ${ }^{21}$ According to my argument, the differing scale and role attributed to musing on the "technological view" in the first film Cube and the big film Splice of Natali circumscribe the space which allows for suggesting an allegorical dimension, inspired by Laetz and McIver Lopes's idea of genre as type.

While the enumerated first features are truly preoccupied with creating complex film narratives, simultaneously with working within a filmic genre, a decade later the repeated methods that lead to narrative complexity are being simplified to some extent, and also become (a) means to offer allegorical descriptions and/ or statements referring to the same filmic genres. Their big-budget films made a decade later, at first glance betray: the correct and serious re-creation of generic patterns, a characteristic probably determined by the Hollywood studios' aesthetics and ideologies, studios that are involved in the production and/or distribution of these films. However, a more detailed analysis founded on the narratively complex solutions as emerging in the first films and also recreated in these big-budget hits reveals that Splice and Black Swan (and consequently The International and Inception) may be read as being interested in representing the chosen genres of the directors understood as types. Or, in other words, that Splice provides an allegorical representation of horror sci-fi, and the same could be stated in reference to Black Swan and Aronofsky's psycho-thriller, The International and action film, and finally Inception and the noir detection film. After ten years, in the possession of strongly positioned authorial names, not eroded by Oscars, comics, franchises and financial success, these directors embark on creating allegories of the basic genres they are interested in, such allegorical spheres where complex narrative solutions - already there in their first features — may be seen as playing the role of glue or mortar that joins the bricks together.

Thus, in the first films, genre references function in "sincere", referential modes, with narrative complexity capturing the main part of the audience's attention. Meanwhile in the big-budget hits, where mise-en-scène, stars and spectacular designs are strikingly different, we may find the same narrative preoccupations of generating narrative complexity through compression/deconstruction/sim-

${ }^{20}$ V. Sobchack, Screening Space: The American Science Fiction Film, 2nd ed., New York 2001 [1987], p. 30.

21 V. Sobchack, op. cit., p. 38. Sobchack refers to S. Sontag, "The imagination of disaster", [in:] Against Interpretation and Other Essays, London 1966, p. 151. 
plification of time, space, focalizer subjectivity, and plot understood as causal chain (methods well known to the audience thanks to the auteur status of the filmmakers). However, genre usage is neither simply imitative, nor reflective and re-interpretative. I have dubbed this mode of genre usage allegorical, in the sense that the films' excessive visual, auditive and narrative designs allegorize what Laetz ad McIver Lopes call the type of the genre - which does not depend on any particular film to exist.

\section{Bibliography}

\section{Secondary sources}

Altman R., “A semantic/syntactic approach to film genre”, [in:] Film Genre Reader IV, ed. B.K. Grant, University of Texas Press, Austin 2012 [1986], pp. 27-41.

Ang I., "Navigating complexity: From cultural critique to cultural intelligence", Continuum: Journal of Media \& Cultural Studies 25, 2011, no. 6, pp. 779-794.

Bókay A., Irodalomtudomány a modern és a posztmodern korban, Osiris Kiadó, Budapest 1997.

Bordwell D., "Film futures", [in:] Poetics of Cinema, Routledge, New York 2007, pp. 171-187.

Buckland W., "Introduction: Puzzle plots", [in:] Puzzle Films: Complex Storytelling in Contemporary Cinema, ed. W. Buckland, Wiley-Blackwell, Malden 2009, pp. 1-13.

Buckland W., "Making sense of Lost Highway", [in:] Puzzle Films: Complex Storytelling in Contemporary Cinema, ed. W. Buckland, Wiley-Blackwell, Malden 2009, pp. 42-61.

Buckland W., ed., Puzzle Films: Complex Storytelling in Contemporary Cinema, Wiley-Blackwell, Malden 2009.

Buscombe E., "The idea of genre in the American cinema", [in:] Film Genre Reader IV, ed. B.K. Grant, University of Texas Press, Austin 2012 [1986], pp. 12-26.

Cameron A., Cubbitt S., "Infernal Affairs and the ethics of complex narrative", [in:] Puzzle Films: Complex Storytelling in Contemporary Cinema, Wiley-Blackwell, Malden 2009, pp. 151-166.

Elsaesser T., "The mind-game film", [in:] Puzzle Films: Complex Storytelling in Contemporary Cinema, ed. W. Buckland, Wiley-Blackwell, Malden 2009, pp. 13-41.

Ghislotti S., "Narrative comprehension made difficult: Film form and mnemonic devices in $\mathrm{Me}$ mento", [in:] Puzzle Films: Complex Storytelling in Contemporary Cinema, ed. W. Buckland, Wiley-Blackwell, Malden 2009, pp. 87-106.

Grant B.K., Kurtz M., "Introduction", [in:] Notions of Genre: Writings on Popular Film before Genre Theory, eds. B.K. Grant, M. Kurtz, University of Texas Press, Austin 2016, pp. 1-10.

Grindon L., "Cycles and clusters: The shape of film genre history", [in:] Film Genre Reader IV, ed. B.K. Grant, University of Texas Press, Austin 2012, pp. 42-59.

Laetz B., McIver Lopes D., "Genre”, [in:] The Routledge Companion to Philosophy and Film, eds. C.R. Plantinga, P. Livingstone, Routledge, London-New York 2009, pp. 152-161.

Schweinitz J., Film and Stereotype: A Challenge for Cinema and Theory, transl. L. Schleussner, Columbia University Press, New York 2011.

Simons J., Playing the Waves: Lars von Trier's Game Cinema, Amsterdam University Press, Amsterdam 2007.

Sobchack V., Screening Space: The American Science Fiction Film, 2nd ed., Ungar, New York 2001 [1987].

Sontag S., "The imagination of disaster", [in:] S. Sontag, Against Interpretation and Other Essays, Picador, Farrah, Straus, Giroux, New York 1966, pp. 209-225. 
Thanouli E., Post-Classical Cinema: an International Poetics of Film Narration, Wallflower, London 2009.

Wedel, "Backbeat and overlap: Time, place and character subjectivity in Run, Lola, Run", [in:] Puzzle Films: Complex Storytelling in Contemporary Cinema, ed. W. Buckland, Wiley-Blackwell, Malden 2009, pp. 129-150.

\title{
Online sources
}

Virginás A., "Elsőfilmek és müfaji allegóriák. Komplex narratív eljárások Natali, Aronofsky, Tykwer és Nolan filmjeiben”, Metropolis 1, 2012, pp. 56-71, http://www.metropolis.org. hu/?pid=16\&aid=451 (accessed: 21.12 .2017 ).

\section{Filmography}

Black Swan, dir. D. Aronofsky, USA 2010.

Cube, dir. V. Natali, Canada 1997.

Following, dir. Ch. Nolan, UK 1998.

Inception, dir. Ch. Nolan, USA-UK 2010.

The International, dir. T. Tykwer, USA-Germany-UK, France 2009.

Perfume: The Story of a Murderer, dir. T. Tykwer, Germany-France-Spain, USA 2006.

$P i$, dir. D. Aronofsky, USA 1998.

Run, Lola, Run, dir. T. Tykwer, Germany 1998.

Splice, dir. V. Natali, Canada-France-USA 2009.

\section{Film genre patterns and complex narrative strategies in the service of authorship}

\author{
Summary
}

From the Euro-American canon of contemporary filmmaking a selection of films has been made, the directors of which transition from low-budget, arthouse, regional first features made in the years 1997-1998 (mainly Cube and Pi, with occasional references to Run, Lola, Run and Following) to big-budget, Hollywood-funded blockbusters presented in the years 2009-2010 (Splice and Black Swan, occasionally referring to The International and Inception). Within this framework the issue of how generic patterns are used by these directors fond of narrative complexity is discussed. While in the debut features narrative complexity is the main issue, leading to a revisionist usage of sci-fi (Natali) and psychological thriller/horror (Aronofsky), as well as action film (Tykwer) and noir detection film (Nolan), in the 2009-2010 blockbusters narrative complexity is hidden behind apparently sincere generic imitation. This latter procedure, on closer inspection, reveals the allegorical re-creation of genres as types (as defined by Laetz and McIver Lopes in The Routledge Companion to Film and Philosophy). The aim is to examine narratively complex designs as tools in establishing the authorial names of these directors, based on their first features, with attention paid to the consistency of film genres referenced. 